\title{
Ideology and intertextuality: Intertextual allusions in Judith 16
}

\begin{abstract}
Authors:
S. Philip Nolte ${ }^{1}$

Pierre J. Jordaan ${ }^{1}$

\section{Affiliations:}

${ }^{1}$ School of Biblical Studies and Bible Languages, North-West University, Potchefstroom Campus, South Africa

Note:

This article is a reworked version of a paper presented at the 'Association for the Study of the Septuagint in South Africa' (LXXSA) on 12 September 2010 at NorthWest University, Vaal Triangle Campus, South Africa.
\end{abstract}

Correspondence to: Philip Nolte

Email:

philip.nolte@iburst.co.za

Postal address:

PO Box 22023, Lyttelton

0140, South Africa

\section{Dates:}

Received: 19 Oct. 2011

Accepted: 03 Mar. 2011

Published: 03 Oct. 2011

How to cite this article: Nolte, S.P. \& Jordaan, P.J., 2011, 'Ideology and intertextuality: Intertextual allusions in Judith 16', HTS Teologiese Studies/ Theological Studies 67(3), Art. \#966, 9 pages. http:// dx.doi.org/10.4102/hts. v67i3.966

(C) 2011. The Authors. Licensee: AOSIS OpenJournals. This work is licensed under the Creative Commons Attribution License.
This article utilised the theory of intertextuality to investigate the way in which religious texts, specifically Judith 16 , generate meaning in the act of the production of texts. The groundbreaking work on intertextuality done by Julia Kristeva served as the theoretical point of departure. Kristeva utilised Mikhail Bakhtin's literary theory to develop her own views on intertextuality. According to the theory of intertextuality, all texts are intersections of different texts and are therefore polyvalent. The article argued that the ideology (or ideologies) of author(s) of texts underpin the ways in which other texts are used and alluded to. The purpose of the investigation was to illustrate how intertextual allusions in Judith 16 are used to describe 'God/the Lord' as a God of war and, thereby, to maintain an already existing ideology of war:

We know now that a text is not a line of words releasing a single 'theological' meaning (the 'message' of the Author-God) but a multi-dimensional space in which a variety of writings, none of them original, blend and clash. The text is a tissue of quotations drawn from the innumerable centres of culture.

(Barthes, cited in Beal 1992:27)

\section{Introduction}

An overview of literature on intertextuality shows that trying to describe intertextuality is a complex issue, ${ }^{1}$ for example:

- Text does not only refer to written texts, or works of literature, but also to other signifying structures such as nature and natural phenomena, movies, music, paintings, people, cultural artefacts and social codes.

- There is no so-called mainstream definition of intertextuality.

- Intertextuality entails more than when one text verbally quotes another text. It also covers allusions to other texts, works of visual art, underlying ideologies, theologies and mythologies.

- Readers do not always have knowledge of texts alluded to in the texts they read.

It seems that intertextuality was, and sometimes still is, used in biblical criticism as a synonym for tradition criticism and form criticism (Phillips n.d.:2-3; Van Aarde 2009:1). However, literary theorist, Jonathan Culler ([1981]2001:103), makes biblical scholars aware that the study of intertextuality is not equivalent to an investigation of sources and influences, as has traditionally been understood. The focus is rather to force scholars to explore the comprehensive social, political, religious and cultural environment in which texts are generated.

In secondary literature on the book of $J u d i t h^{2}$, commentators portray a large number of intertextual links between Judith and other biblical and extra-biblical literature. However, none of these texts explore the theme that we pursue in this article, namely the way in which intertextual allusions in Judith 16 reinforce an already existing ideology of war, and of YHWH as God of war, in Second Temple Judaism. This investigation consists of six parts. Part one provides an overview of secondary literature on Judith. Part two represents a concise reflection on the theories of Mikhail Bakhtin ([1981]1987, 1984) and Julia Kristeva (1980), as well as a short description on the concept of ideology, whilst part three consists of a brief description of ideology and ideological criticism as it pertains to the study in this article. Different intertextual allusions as presented in Judith 16 will be investigated in part four and an indication of how these allusions are used to maintain an ideology of war will be provided in part five. The final part will offer a summary of the findings of this investigation.

\section{Overview of secondary literature}

The following summary gives an indication of some of the intertextual links commentators find in the book of Judith.

To gain some insight into the complexity of this topic see: Adolphe Haberer (2007.54-57) Mary Orr ([2003]2008) Zuzana Mitošinkova (n.d.:64-68), Peter Phillips (n.d.), Ellen van Wolde (1997:426-451), Timothy Beal (1992:27-39), Peter Miscall (1992:41-56), Ilona Rashkow (1992:57-73), and Michael Worton and Judith Still ([1990]1991).

2.When referring to the character of Judith, 'Judith' will be written in normal text, whereas references to the text or narrative will be written in italics. The Greek text and English translation we used is the version as published in The Septuagint with apocrypha: Greek and English by Sir Lancelot C.L. Brenton ([1986]2007). 
Toni Craven (1983) makes a valuable contribution with regard to available studies on Judith. Her approach and method falls in the category of literary and rhetorical criticism, with a particular focus on what she calls 'compositional analysis' (Craven 1983:21). We find various references to possible intertextual allusions in her discussion of the sixteenth chapter of Judith, but her method prevents her from discussing a possible ideological framework. This methodological hindering can be illustrated by two references in Craven's book. The first is found in her discussion of Judith 16, where she gives a very short description about the similarities in terms of function, form and content between Judith 16 and Exodus 15 (Craven 1983:111-112). This portrayal is in line with Craven's methodology, with no attempt to investigate the way in which Exodus 15 is utilised in Judith to maintain the view that YHWH takes Israel's side in the war against the Assyrians.

In the last chapter of her book, Craven (1983:114-116) discusses the theme of 'convention versus tradition'. In this section, Craven (1983:114) places Judith in the broader framework of the traditional belief that God is 'the creator/ redeemer God known in history' and links it to what is said about God in Psalm 149:6-7/7-8 (depending on which English translation one uses). The translation used in Craven (1983:114) is as follows: 'Let the high praises of God be in their throats, and two-edged swords in their hands, to wreak vengeance on the nations and chastisements on the peoples'. Craven (1983:114) states that this idea about God was known to the Jewish people and that the book of Judith is meant to 'insure and preserve the continuance of authentic Yahweh worship'. In other words, YHWH is associated here with war and as a God who helps his people to take revenge on their enemies. The underlying ideology is that war in YHWH's name is acceptable. Unfortunately, Craven does not develop the possibilities which she herself opened up with her reference to Psalm 149.

Various scholars (DeSilva 2002:95-96; Dombkowski Hopkins [1992]1998:283; Esler 2001:75-76; Harrington 1999:29; Jordaan \& Kanonge 2006:75; Nickelsburg 2005:100; Steyn 2008:157; Van Henten 1994:33; White 1992:5-16) also argue in favour of similarities between Judith and other narratives in the Old Testament where female characters take central position, such as the stories about Miriam (Ex 15:20-21), Deborah and Jael (Jdg 4-5), the woman of Thebez (Jdg 9:53-54), as well as the woman of Abel-beth-maacah (2 Sm 20:14-22). Our attention is therefore focused on a number of similar intertextual connections. Firstly, the connection between Achior in Judith 5-6 and Abraham in Genesis 15 (DeSilva 2002:96; Roitman 1992:39-40). Secondly, Judith's (9:2-4) use of the episode of Simeon and Levi's vengeance upon Shechem in Genesis 34 to justify her murder of Holofernes (DeSilva 2002:96; Dombkowski Hopkins 1998:283). Thirdly, the incidents at Massah and Meriba related in Exodus 17 and Numbers 20 as a meaningful layer of intertexture for reading Judith 7:19-32, in which the episode of the shortage of water in Bethulia is narrated (Van Henten 1995:233-236). Lastly, a connection between Moses' striking of the rock at Meriba (Ex
17:6) and Judith's beheading of Holofernes (Jdt 13:4-8) (Van Henten 1995:236).

Other intertextual connections are also relevant in this regard, such as those proposed by Jan Willem van Henten (1994:37-46), who finds close links between Judith 7-13 and Exodus 17, Numbers 20 and Deuteronomy 33 and also shows how Judith (8:12) used the stories of Abraham, Isaac and Jacob to motivate the elders in Bethulia not to put God to the test (Van Henten 1994:40, 41). Philip Esler (2001:64-101) investigates Judith from a cultural anthropological framework, specifically against the background of the so-called pattern of challenge and response as part of the social dynamic of ancient Mediterranean cultures (see Malina 2001:33-43). From this theoretical vantage point, Esler (2001:78-98; see also Nickelsburg 2005:100) argues in favour of a connection between the Judith story and the David and Goliath story in 1 Samuel 17 (LXX). David deSilva (2002:97-98) concurs with Mark Caponigro's (1992:47-59) theory that the Greek author Herodotus's account of the Persian invasions of Greece in the 5th century BCE (Historiae 6.48, 94; 7.131-133) influenced the Judith narrative. Denise Dombkowksi Hopkins (1998:279-285) argues in favour of intertextual themes between Judith and 'Woman Wisdom' (Pr 1:8, 20-21, 23; 3:12; 5:1; 8:6, 32, 34-35; 9:8). Jennifer Glancy (1996:84-86) highlights the irony of the deferred liberation of Judith's female slave by referring to passages in Deuteronomy and Jeremiah as intertextual links. On the one hand, Judith tells Holofernes that Israel will be defeated when they do not obey God (Jdt 11:12-13). But on the other hand she does not act according to the law which states that Israelites must release their Hebrew slaves in the seventh year (Dt 15:12). Jeremiah condemns the Israelites for neglecting this aspect of the Law (Jr 34:12-22). Finally, Helen Efthimiadis-Keith (2002:64-84) focuses on what she calls the 'obfuscation and blurring of gender boundaries' and 'which gender kills' by reviewing the way in which Judith is depicted in the text, in scholarly commentaries and in paintings of Judith from the Renaissance to the present time. Efthimiadis-Keith (2002:80-82) closes her article by relating the depiction of Judith in many of the art works with what Carl Jung calls the anima. This study shows that the concept of 'text' does not only refer to literature alone and that there exists a variety of intertextual allusions between paintings and literature. It also shows how scholars' and painters' cultural ideologies influence their description and depiction of Judith. Efthimiadis-Keith's analysis underscores one of the premises in our article, namely that texts (literature and works of art) reflect the ideological points of departure of authors and artists.

\section{Theories of intertextuality Mikhail Bakhtin}

The concept of 'intertextuality' was first developed by the Bulgarian born psychoanalyst, linguist, philosopher and sociologist, Julia Kristeva. Kristeva utilises and develops the 
concept of 'dialogism', which was introduced by Russian literary theorist, Mikhail Bakhtin ${ }^{3}$, as her point of departure.

For the purpose of this article we are interested in Bakhtin's distinction between dialogic and monologic notions of truth (Newsom 2000:24). Monologic truth is conceived of as propositional statements which can be organised into a unified system, for example, systematic theology or dogmatic propositions. It also suggests that a text is a closed unit of meaning, without the possibility of being influenced and/or contradicted or questioned by other texts. Traditional linguistics and stylistics treated words and discourses as if texts are self contained systems with no relation to anything else but their own closed context and linguistic world (Bakhtin [1981]1987:276). This means that traditional linguistics allows no room for disputation and questioning of its own theories and methods, which has the consequence that dialogue between different discourses is, in principle, not possible and therefore any communication is obstructed from the start. Unified and contained systems of thought have the tendency to be totalitarian in the sense that they exercise control over the way in which communities see the world and understand their everyday life. Powers that be in communities decide what truths are valid and what truths are not valid in order to establish and maintain the power structures conducive for keeping them in power.

Dialogic truth, on the other hand, 'requires a plurality of consciousnesses ... [that] in principle cannot be fitted within the bounds of a single consciousness' (Bakhtin 1984:81). Whereas monological truth is constituted by abstract ideas, dialogical truth can be described as an open-ended dialogue by people who cannot be contained by defining them and who are 'unfinalizable'. In other words, for Bakhtin, dialogism indicates an:

open-ended, back-and-forth play between the text of the sender (subject), the text of the addressee (object), and the text of culture. In so doing he [Bakhtin] introduces a dynamic instability which is unallowable in formalisms and structuralisms.

(Beal 1992:29)

This 'dynamic instability' flows from the acknowledgement that discourse is a social phenomenon and that it forms part of a vast universe of textual worlds.

Words and discourses generate their meaning at particular historical moments and in socially specific environments, and:

cannot fail to brush up against thousands of living dialogic threads, woven by socio-ideological consciousness around the given object of an utterance; it cannot fail to become an active participant in social dialogue.

(Bakhtin [1981]1987:276)

Texts are situated and embedded within history and society, which, in turn, become texts read by readers and writers. A

3.Bakhtin lived through the years of the Russian Revolution and then under the imperialistic rule of Stalin. He was arrested in 1929 due to alleged activities in the imperialistic rule of Stalin. He was arrested in 1929 due to alleged activities in the underground Russian Orthodox Church and sentenced to a Siberian labour camp. intervention of influential friends. Bakhtin's cultural and historical back intervention of influential friends. Bakhtin's cultural and historical background is important to help us understand why his conception of language is mainly social (Haberer 2007:57). reader becomes a writer and a writer, to be a writer, always has to remain a reader - of texts, of history, of society. Therefore, for Bakhtin, writing is a reading of preceding literary corpuses and texts are absorptions of and replies to other texts. Timothy Beal (2000) formulates this intricate interweaving of texts and intertextual allusions as follows:

Intertextuality is a theory that conceives of every text as a set of relations between texts, an intersection of texts that are themselves intersections of other texts, and so on. Every text is a locus of intersections, overlaps, and collisions between other texts. Every text is an intertext, that is, a between-text (inter, 'between'), a paradoxical locus of dislocation, without center and without boundaries.

(Beal 2000:128)

In terms of the focus of this article, this means that intertextual allusions in Judith 16 form part of already existing discourses and ideologies about the relationship between God and his people, which were known to readers and writers and which were used to construct a story meant to maintain and/or challenge existing discourses. These discourses include and exclude, they befriend and alienate, they are overlain with values and qualifications, and they are opened or closed to dispute. As such, these discourses are, as Bakhtin ([1981]1987) states:

... from one side highlighted while from the other side dimmed by heteroglot social opinion, by an alien word about them. And into this complex play of light the word enters - it becomes saturated with this play, and must determine within it the boundaries of its own semantic and stylistic contours.

(Bakhtin [1981]1987:277)

The intertextual allusions in Judith 16 enter the prism of the author's ideology as rays of light and what we have before us is a rainbow - a new text in the form of a colourful combination of existing ideologies and texts which has the potential to guide people in a new situation. To reflect further on this play of light, we now move on to a short description of Kristeva's theory on intertextuality.

\section{Julia Kristeva}

Kristeva4 (1980:64-89) develops Bakhtin's ideas further and argues that literary structure does not simply exist, but is always generated in relation to another structure. This opens up a dynamic view on what texts are and how they function in societies. Words, discourses and texts are not static, fixed and closed entities, but form part of larger universes of dialogues which include at least three dimensions, namely the writer(s) (author[s]), the addressee(s) (listener[s], reader[s]) and the

4. Kristeva arrived in Paris, France in the mid-1960s, superbly equipped to introduce the work of Bakhtin to Western intellectuals (Moi 1986:2). She immediately became part of the so-called Tel Quel group, which was a centre of gravitation for almost al of the younger generation of structuralist and emerging post-structuralist theorists in France (Moi 1986:4). Kristeva's academic work from this period onwards has to be understood against the background of the political changes which took place in France, especially from the time of the revolt in May and June of 1968 (Mo 1986:5-9). As with Bakhtin, Kristeva had a solid grounding in Marxist theory, which led her not only to develop a critical relationship with intellectuals in Western Europe, but also to maintain a critical stance against Maoism as it developed in Europe, but also to maintain a critical stance against Maoism as it developed in China during that time. It was Kristeva's experience of a visit to China with othe intellectuals which made her 're-evaluate her political positions and decide to settle for a more localized interest in the individual, thus in effect abandoning her previous interest in a more general, political engagement' (Moi 1986:6). Eventually, this shift in intellectual interests led her to begin training as a psychoanalyst and move away from purely linguistic or semiotic work, which culminated in the publication of Revolution in poetic language. 
contemporary or earlier cultural context. Kristeva (1980) formulates this insight as follows:

What allows a dynamic dimension to structuralism is his [Bakhtin's] conception of the 'literary word' as an intersection of textual surfaces rather than a point (a fixed meaning), as a dialogue among several writings ...

(Kristeva 1980:65)

The dynamic of a text lies in the idea that it is an intersection of different texts and, because of that confluence of different texts, no text is really original, but rather a space where different voices meet. What makes the new text unique, though, is the way in which it relates to other texts, that is, the way in which it either agrees with other texts, or differs from them, and the way in which it enters into a dialogue with those texts.

Kristeva (1980:66) utilises the metaphor of a mosaic to describe her interpretation of Bakhtin's insights. A mosaic presents an interplay of a wide variety of colour and different sizes and types of material. Although a mosaic is a historically specific display of someone's interpretation or creation of an idea, the mosaic itself is not a static, fixed point in time. It can be developed further. It is, itself, an intersection of different patterns and colours and styles which form part of the creator's repertoire. It takes over stylistic features from earlier and/or contemporary artists and masters. But it is always a new creation. It carries the signature, as it were, of the person who created it. It not only presents - it always consumes and incorporates, and at the same time it alters that which it borrows from into something else. In the same way, says Kristeva (1980:66): ' ... any text is the absorption and transformation of another'. Creators of texts are in dialogue with other texts constantly, even if they are not consciously aware of it. They draw upon an array of information on the same theme or related themes, societal and cultural forces and discourses, prejudices, and personal experiences. This wide range of influences plays a significant role in shaping the way texts are created. Texts (or creators of texts) take up, consume, incorporate and absorb other texts and, at the same time, these intertextual threads are altered and remodelled into something else - into the text the author wants it to be. For Kristeva, meaning cannot be viewed as a finished product, but it is always in a process of production.

For Kristeva (1980), Bakhtin's notion that dialogue or dialogism is inherent in language itself is of great significance, because:

Bakhtinian dialogism identifies writing as both subjectivity and communication, or better as intertextuality. Confronted with this dialogism, the notion of a 'person-subject of writing' becomes blurred, yielding to that of 'ambivalence of writing'.

(Kristeva 1980:68)

'Ambivalence' indicates the relation between society (culture or history) and texts and, for the writer, these two are one and the same. This has to do with what Bakhtin calls a translinguistic science (Kristeva 1980:69), which facilitates the understanding of intertextual relationships. Through constant dialogue with preceding texts, 'new' texts perpetually challenge the past, which has the effect that definition or truth, or a hierarchical constellation of propositions, does not exist in this interaction. Although Kristeva (and Bakhtin) is reflecting on 'poetic language' (not identical with poetry), the same can be said about 'scientific' language. In a postmodern world, theories and methods are constantly challenged by new discourses and it is also realised that all these discourses are built upon subjective agendas and power relations.

Ellen van Wolde (1997:427-429) criticises Kristeva's view of intertextuality as being too vague, as well as of displacing Bakhtin's emphasis on text production in interaction with other texts and with reality in favour of an all-embracing view of text. Van Wolde's critique is of value for our study because of her insightful reflection on 'genotext' and 'phenotext', as well as her description of intertextuality as related to text production, on the one hand, and intertextuality as related to text reception, on the other. Textual elements or patterns are both repeated and transformed in order to be assimilated into new text structures (Van Wolde 1997:429). The process of repetition and absorption forms part of a larger dynamic of text production and text reception. Text production relates to the author of a text and can be called the first text, or genotext, whereas text reception is related to the reader and/ or listener and can be called the second text, or the phenotext. Intertextuality is operative both in the production or writing process of a text and in the reception or reading of a text.

If texts are intersections of an indeterminate number of textual surfaces, this implies that every text 'suggests an indeterminate surplus of meaningful possibilities. Interpretation is always a production of meaning from that surplus' (Beal 1992:31). Reflection on what the production of texts entails, leads one to ponder the question: who or what controls the means of production? In this way, intertextuality opens to ideological criticism.

\section{Ideological criticism}

Ideological criticism is not the name for a method such as source criticism, or redaction criticism, but it is more a hermeneutical stance. This hermeneutical stance makes us sensitive to the fact that all of us are formed and informed by the cultures in which we live and the specific ideological lenses through which those cultures view reality. Ideologies function and are embraced or negated because the worldviews advocated by them ring true to their adherents. For example:

- For Christians who read the Bible in a fundamentalistic way, an ideology that accepts the literal existence of a devil or angels, or a hell, sounds true and is therefore accepted without thinking.

- White supremacists in South Africa have no problem seeing Black people as inferior. They sometimes label Black people using references from biblical texts, such as 'the children of Ham', which means that they are not part of God's chosen people. 
- Capitalism, consumerism and a global market form part of a larger ideology that makes it acceptable to exploit natural resources and people.

- The French theorist, Louis Althusser ([1971]1994:100-151), refers to what he calls 'state apparatuses', which keep the State in power. Althusser goes further and distinguishes between 'repressive state apparatuses' such as the government, army, legal system and police power, which operate by violence and repression. But, according to Althusser, 'ideological state apparatuses' most effectively keep the dominant power and classes in their place. In her reflection on ideology and ideological criticism, Beverly Stratton (2000:121) formulates this as follows:

In contrast to the 'repressive state apparatuses' that wield their power through force, ISAs [ideological state apparatuses] include those aspects of culture and society that most of us willingly embrace, such as schools, religions, the media, and other means of inculcating values and shaping worldviews. For Althusser, what ISAs and ideology do is to represent 'the imaginary relationship of individuals to their real conditions of existence'.

Althusser evaluates ideology and the role it plays in societies from a Marxist theoretical viewpoint as 'false consciousness' that allows both dominant and oppressed classes to perpetuate their uneven class relationships.

We understand who we are and what our place in the world is by means of the ideologies that we recognise and embrace, as well as those we discern and repudiate (Stratton 2000:122). Ideologies relate to the culture of a society and to the sum of its prejudices and preconceptions by way of ideas, myths, images and concepts. Most of the time, ideology is transmitted on an unconscious level because it is usually taken for granted and considered as 'natural' (e.g. boys wear blue and girls wear pink).

Anthropologist Clifford Geertz (1964:63) describes ideologies in a more neutral sense than Althusser, as 'schematic images of social order', which means that our interpretation of reality is affected by the ideologies or modes of discourse that shape us. James Kavanagh (1990:310-311) also views ideology in a neutral sense as a 'system of representations' expressed in material practices. These practices help individuals to internalise an 'appropriate' picture of their social world and their place in it. Ideology thus becomes a 'natural' framework, an 'obvious reality' that people can accept as if it had not been socially constructed. This kind of thinking permeates the whole of the Judith narrative. We see it in Holofernes' imperialist ideology and in Judith's ideology that YHWH is on the side of the Jews when they are obedient to him.

Ideological criticism is employed by biblical scholars for a variety of reasons - see Stratton (2000:123) for more examples:

- to uncover and expose the social and political realities of the communities for which texts were originally written and the way in which it communicated with and influenced their original communities

- to investigate and challenge dominant readings of texts using deconstructive criticism
- to define ideology in relation to the reader as practiced by feminist theologians, liberation theology and postcolonial interpreters.

When reflecting on the question of whether texts have ideologies, Stratton (2000) writes as follows:

This seems obvious, since authors are part of a particular society that shapes their worldviews. Authors likewise intend to shape readers by structuring poetic lines, portraying characters, using narratorial perspective and rhetoric strategies, and delivering arguments in ways that either support or challenge a community's governing ideologies.

(Stratton 2000:124; also see Efthimiadis-Keith 2002:64-84 as illustration of this insight)

Some critics, such as Meir Sternberg $(1985: 37,50)$, come to the conclusion that the Bible has such a 'foolproof composition' that it inevitably succeeds in indoctrinating and therefore it is impossible to counter-read biblical passages. Other scholars, such as feminist researchers, differ from Sternberg's view and expose multiple ideologies in the Bible, many of which oppress particular groups of people, as well as certain texts which help to liberate them (see Ruether 1983). In additional, a large number of scholars ${ }^{5}$ argue that texts do not have ideologies, but people do. They argue the Bible has been (ab)used to fit and underpin as many ideologies as there are people reading the Bible.

Our viewpoint is that texts reflect the ideologies by which people live. We investigate Judith 16 from the hermeneutical stance that meaning is not fixed or static, but is continuously produced by the interaction amongst authors, texts and readers. Texts and their interpretations are shaped through a struggle between competing ideologies; there is no valueneutral interpretation or scholarship (Stratton 2000:126). This hermeneutical stance corresponds with what we have argued above on intertextuality and it confirms the validity of an intertextual reading of a text such as Judith 16 . Our endeavour is to show that intertextual allusions in Judith 16 serve the purpose to strengthen the so-called Deuteronomistic theology (ideology), as well as forwarding an ideology of war by picturing YHWH as a God of war. However, the space for an article such as this does not allow a discussion of all the intertextual allusions in Judith 16, therefore only two cases will be discussed, namely Judith 16:3, 15, 17 and Judith 16:5, 12c-13a. The reason for selecting these passages will become clear in the following description.

\section{Intertextual allusions in Judith 16 Judith 16 and Psalm 46 (Psalm 45 in the Septuagint $)^{6}$}

The intertextual links between Judith 16 and Psalm 46 do not lie in verbatim quotations by the author of Judith from Psalm 46 , as much as it can be traced in allusions or hints which are represented by expressions corresponding with one another. These expressions consist of, (1) natural phenomena related 5.See Stratton (2000:124-126) for a short discussion and bibliography on this issue.

6.The English translation used is the New International Version text as it is contained in The NIV Serendipity Bible for study groups (1989, 2nd edn.). 
with the appearance and intervention of God and (2) battles being broken by God:

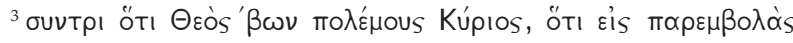

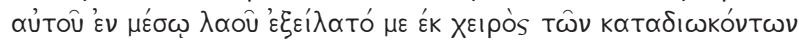
$\mu \varepsilon$

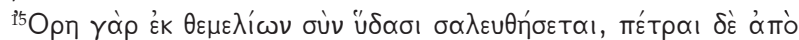

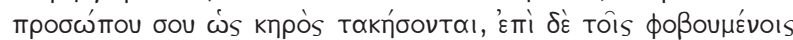
aن่Tôs.

${ }^{17}$ Oủai '

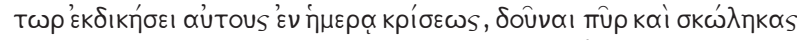

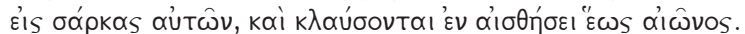

${ }^{3}$ For God breaketh the battles: for among the camps in the midst of the people he hath delivered me out of the hands of them that persecuted me.

${ }^{15}$ For the mountains shall be moved from their foundations with the waters, the rocks shall melt as wax at thy presence: yet thou art merciful to them that fear thee.

${ }^{17}$ Woe to the nations that rise up against my kindred! the Lord Almighty will take vengeance of them in the day of judgment, in putting fire and worms in their flesh; and they shall fell them and weep for ever.

(Jdt 16:3, 15, 17)

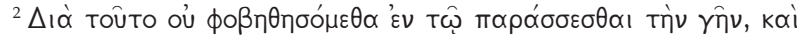

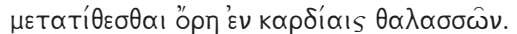

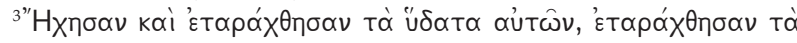

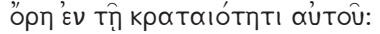

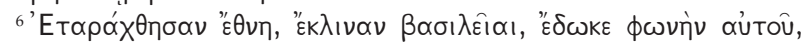

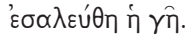

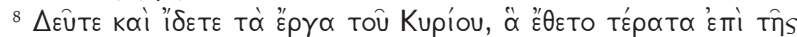

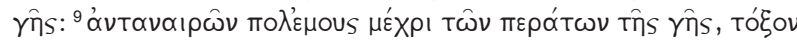

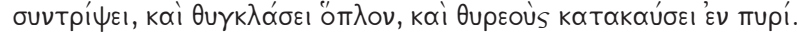

${ }^{2}$ Therefore we will not fear when the earth is troubled, and the mountains are removed into the depths of the seas.

${ }^{3}$ Their waters have roared and been troubled, the mountains have been troubled by his might.

${ }^{6}$ The nations were troubled, the kingdoms tottered: he uttered his voice, the earth shook.

${ }^{8}$ Come and behold the works of the Lord, what wonders he has achieved on the earth. ${ }^{9}$ Putting an end to wars as for the ends of the earth; he will crush the bow, and break in pieces the weapon, and burn the bucklers with fire.

(Ps 46:2-3, 6, 8-9)

Let us first consider the overall tone of the two passages. The disposition in Judith 16 is quite different from that in Psalm 46. Judith's song of praise is permeated by a spirit of vengeance against the enemies of Israel, whereas Psalm 46 speaks of peace amongst nations. God delivers Judith out of the hands of the Assyrians, after she murdered Holofernes, and God gives the soldiers of Israel strength to destroy the Assyrian army. No mention of war between nations is made in Psalm 46.

Both passages refer to God's act of 'breaking the battles' or 'ending wars' (Jdt 16:3; Ps 46:9). However, there is a large difference in underlying ideologies. Judith 16 is adamant about the conviction that God is on the side of the Israelites. The words in Judith 16:3, 'For God breaketh the battles', pertain to Judith being rescued from the Assyrian camp and Israel destroying their enemies. It does not cross the traditional boundaries between Israel and their enemies. God does not break battles to bring peace between nations and no reference to peace between Israel and Assyria can be found in Judith 16. Nations have to fear God when God appears, because God will destroy them. After using an expression which reminds one of Psalm 46:2-3, 6, Judith 16:15c-17 states that there exists a clear boundary between $\mathrm{YHWH}^{\prime}$ s people and other nations. The latter are the nations who make war against Israel, in this instance Assyria, and they will be ousted to the kingdom of death where $\mathrm{YHWH}$ will put 'fire and worms in their flesh; and they shall feel them, and weep for ever'. In other words, Israel does not have to be afraid of God, but their enemies will be struck by God's wrath. We find no picture here of a God who is the God of mercy to all, but only to Israel. This is quite the contrary to what we find, for example, in Isaiah 8:1-8 where God is said to use the Assyrians as his instrument to God's own people, as well as in Jeremiah 27, where God puts his people as slaves into the hand of Nebuchadnezzar. We find a picture of an exclusive nation with an exclusive God in Judith 16. Verse 12 even says that Israel's enemies 'perished by the battle of my Lord'. God is depicted as a God who makes war and who is merciful only to those who fear him and not to all the nations.

In Psalm 46:8-9 the nations are summoned to witness God's deeds. We are confronted with a picture that inspires awe and fear in people, because verse 6 states that the earth melts away when God appears and speaks. The first hearers and readers of the Psalm would be inclined to ask themselves: 'What are these works of God? Is it the destruction of our enemies? Are we at last going to be free of the Assyrians and the Babylonians forever? Will we live to see how God crushes our enemies?' Then, the unexpected answer: 'No, on the contrary, God makes an end to all wars'. Instead of destruction of the nations, a peaceful solution is proposed. God's deeds are not to destroy Israel's enemies through war and the atrocities associated with war, but by making peace between nations and by destroying weapons of war. W.S. Prinsloo (1984:78) shows that the exhortation in verse 10a, namely, 'Be still, and know that I am God', has to be read in combination with the foregoing description of God's great deeds in verse 9 . Therefore, to be silent before God, in this instance, is to acknowledge that God does not destroy nations or incite war between Israel and her enemies, but follows a path of peace. The Holy War tradition is used in verse 10 to picture $\mathrm{YHWH}$ as warrior, but we find a significant difference with the conventional idea of YHWH who destroys Israel's enemies. Here, YHWH does not destroy people, but crushes instruments of destruction, the symbols of power. God is depicted as the God of all nations, not only of Israel. Psalm 46 paints a picture of inclusiveness and universal peace over and against the picture of exclusive hatred and war in Judith 16 .

The aforementioned analysis illustrates how themes that are found in a context of peace in Psalm 46 are introduced into a new context in Judith 16 - to write a story in which 'every detail ... was designed to serve a literary and theological purpose' (Moore 1985:78, [author's own emphasis]). The 'theological purpose' is to picture God as a warrior who destroys Israel's enemies. This purpose will be argued further in the following 
paragraphs, where intertextual links between Judith 16 and Psalm 137 are discussed.

\section{Judith 16 and Psalm 137 (Psalm 136 in the Septuagint $)^{7}$}

${ }^{5}$ Eı

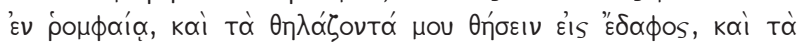

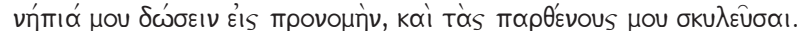

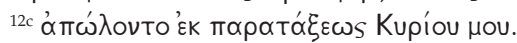

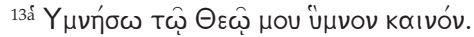

${ }^{5} \mathrm{He}\left[{ }^{\prime}\right.$ Assur'] bragged that he would burn up my borders, and kill my young men with the sword, and dash the sucking children against the ground, and make mine infants as a prey, and my virgins as a spoil.

${ }^{12 c}$... they perished by the battle of my Lord.

${ }^{13 a}$ I will sing unto my God a new song ...

$(\mathrm{Jdt} 16: 5,12 \mathrm{c}-13 \mathrm{a})$

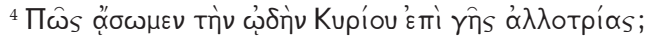

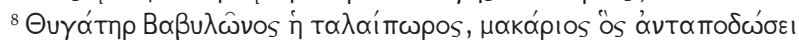

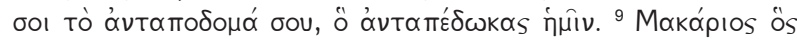

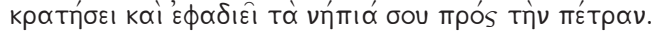

${ }^{4}$ How should we sing the Lord's song in a strange land?

${ }^{8}$ Wretched daughter of Babylon! Blessed shall he be who shall reward thee as thou hast rewarded us. ${ }^{9}$ Blessed shall he be who shall seize and dash thine infants against the rock.

(Ps 137:4, 8-9)

Judith is able to sing a new song of praise because God humiliated the enemy, for what we have in Judith is not only a war between nations, but also a war of gods. The fundamental question is who is God - Nebuchadnezzar or YHWH (Jdt 6:2)? This view is intertextually and ideologically connected to the mythology of the ancient world, in which strife and war between gods was a common occurrence. Judith's new song of praise to God is grounded by the ideological conviction that the war against the Assyrians actually was 'the battle of my Lord' (v. 12). When Carey Moore (1985) discusses the possibility that Judith's song may be modelled on an old synagogal psalm, he makes the following statement which is significant for our argument:

... why would the storyteller have even considered adopting and adapting such a psalm in the first place? The most obvious answer is that the synagogal hymn was already patterned after the Song of the Sea (Exodus 15), a hymn which was not only the song of triumph par excellence but which also had a motif especially appropriate to the Judith-story, namely, the hand of the Lord.

(Moore 1985:256)

It is Carey's reference to 'the hand of the Lord' which is of significance here. Exodus 15 is a song by Moses and Israel to praise God after God has destroyed the Egyptian army by drowning them in the sea. Although we do not argue for or against the intertextual link between Judith 16 and Exodus 15 , what is important here is that the motif of God destroying other people is part of the larger Judaic collective memory and it is not difficult for authors of books such as Judith to make statements like these.

7.The English translation used is the New International Version text as it is contained in The NIV Serendipity Bible for study groups (1989, 2nd edn.).
Judith 16:5 alludes intra-textually to Holofernes' (Nebuchadnezzar's) bragging that he would crush Israel's babies against the ground (Jdt 16:5). But it did not happen. Instead, Holofernes was killed and his army was crushed by the very people he thought would be crushed by him. Intertextually these words can be related to Psalm 137:9, where the person who crushes the babies of Israel's enemies against a rock is called 'blessed'. The poet of Psalm 137 lets himself be dominated by his mounting rage and plunges into the abyss of human emotion and passion. The poet's prayer in verse 7 moves into a direct curse in a particularly refined form in verses 8-9, namely as a word of blessing on the person who will inflict the most cruel revenge on the hated enemy. The psalm reaches a climax in verses 7-9, where Yahweh is urged to think of the evil deeds committed against his people by the Babylonians, and which must culminate in Yahweh's judgement of them. When we read this in combination with the curse in Judith 16:17 the picture painted in Judith 16 becomes even more ominous:

Woe to the nations that rise up against my kindred! the Lord Almighty will take vengeance of them in the day of judgment, in putting fire and worms in their flesh; and they shall feel them, and weep for ever.

(Jdt 16:17)

Although it is not an intertextual allusion to Psalm 137, the theme in Judith 16:17 corresponds to that of Psalm 137:8-9, namely that God is on the side of Israel and will take revenge upon Israel's enemies. The picture of wrath and revenge, and action and reaction, painted in Judith 16 is in agreement with what can be found in the Old Testament.

\section{Ideology of war in Judith $16^{8}$}

Esler (2001:99-100) sees in Judith 'a profound message concerning how the God of the ancient Israelites dealt with his people' and that this God 'exalts the lowly and crushes the arrogant who oppress them'. It may be too simplistic to reduce any literary work to a single theme, but it cannot be denied that the reversal of weak and strong, and male and female, pervades the narrative in Judith. However, an important theme which is not discussed in any of the studies we had at our disposal is the issue of the ideological grounding for crushing the Assyrians.

We believe that God is pictured in Judith as a God of war. The ideology of war in Israel goes back to the stories of the Exodus and the invasion of the so-called Promised Land. The implications of any story depend a great deal on how we construe the shape of the story. The story of the conquest of the Promised Land served the propagandistic purposes of King Josiah, or of later Deuteronomistic editors. Some scholars say that neither Deuteronomy nor Joshua was intended to incite violence against ethnic outsiders, but rather that they were directed against 'insiders who pose a threat to the hierarchy being asserted' (Rowlett 1996:12-13). But this does not relieve the moral problem presented by the story. In the words of James Barr (1993:209), 'the problem is not whether the narratives are fact or fiction, the problem is that,

8.See Brad Kelle and Frank Ames (eds. 2008) for an excellent discussion on different themes pertaining to war. 
whether fact or fiction, the ritual destruction is commended'. The texts authorise one group of people to take the land and slaughter the inhabitants in virtue of a divine command.

The same can be said of the Judith narrative. It is not strange to hear Judith sing a new song about the battle of her Lord. The ideology of a God making war on Israel's behalf and destroying Israel's enemies has been part of Israel's collective memory for many centuries. The claim of divine authorisation for utterly destroying their enemies was not an extraordinary one to make for Israel and for the author of Judith. The problem is that claims such as these dovetail too neatly with the interests of one group, in this instance Israel. Nickelsburg (2005:101) makes the observation that Judith 'is a strongly nationalistic text that celebrates God's victories over the Syrians'. Judith 16 is none other than a divine legitimising of destroying people and this is troublesome.

\section{Findings}

We investigated Judith 16 from the hermeneutical stance that:

- Meaning is not fixed or static, but is continuously produced by the interaction amongst authors, texts and readers.

- Texts and their interpretations are shaped through a struggle between competing and/or parallel ideologies.

- There is no value-neutral interpretation or scholarship.

By drawing on the pioneering work of Bakhtin and Kristeva, we have shown that theories on texts and intertextuality are valuable when reading ancient texts such as Judith. The value of these theories lies, inter alia, in an awareness of the fact that authors and readers are constantly formed and influenced by a wide variety of texts and that these influences crystallise in their writing and reading. Furthermore, it has also been shown that existing texts and ideological themes in Israel influenced the construction of Judith 16 (see also Moore 1985:243-257).

In addition, we showed that the utilisation of theories on ideology and ideological criticism contributes to responsible readings of ancient and influential religious texts such as Judith. The ideology of war underlying Judith's prayer in Judith 16 has been illustrated in the discussion on intertextual allusions with Psalms 46 and 137. It has been shown that certain elements in the two psalms have been used in a new context to justify and maintain the already existent ideology that YHWH makes war against Israel's enemies. This ideology is, inter alia, reflected in Judith's joyful exclamation that the enemy 'perished by the battle of my Lord' (v. 12). Finally, it has been shown that the intertextual artistry of the author maintains the existing ideology of war.

Although it is true that what we perceive as atrocities of war were accepted war practices in ancient times, it is impossible for our generation of readers to ignore problematic issues deriving from reading texts such as Judith 16 . One has to consider the implications of our reading strategies. Scholars such as Nickelsburg (2005:101), DeSilva (2002:95) and Craven (1993:1460) argue that the function of the book is 'didactic fiction'. DeSilva (2002) even states that the author of the story wants to:

present his audience with a model of the kind of piety that can achieve great things for God and God's people. Judith's triumph and the honor that her people heap upon her will rouse emulation in the hearts of the readers, with the result that their own commitment to such piety will be confirmed and energized.

(DeSilva 2002:95)

LeAnn Snow Flesher (2007) agrees with this kind of interpretation and says that:

As such, the story lends itself to more than one historical context and could easily have been reinterpreted and repeatedly pressed into service as a message of hope for more than one tyrannical attack of the Jews by postexilic Hellenistic leaders.

(Flesher 2007:85)

Comments such as these illustrate that the story has the potential of being used as a motivation to keep hatred and revenge between nations alive.

Thus, we have shown that we cannot only read Judith as fine literary artistry, or didactic material, or even as an entertaining story. It has to be read against an Old Testament ideology of war, because that ideology was transmitted from generation to generation and considered as 'natural'. We also have to consider the question of what value and meaning we give to texts such as Judith.

\section{Acknowledgements Competing interests}

The authors declare that they have no financial or personal relationship(s) which may have inappropriately influenced them in writing this article.

\section{Authors' contributions}

S.P.N. did the research for the article and wrote the manuscript. P.J.J. acted as evaluator and critical reader.

\section{References}

Althusser, L., [1971] 1994, 'Ideology and ideological state apparatuses' in S. Žižek (ed.), Mapping ideology, transl. B. Brewster, pp. 100-151, Verso, London.

Bakhtin, M.M., [1981] 1987, 'Discourse in the novel', in M. Holquist (ed.), The dialogic imagination: Four essays, transl. C. Emerson \& M. Holquist, pp. 259-422, University of Texas Press, Austin, TX.

Bakhtin, M.M., 1984, Problems of Dostoevsky's poetics, ed. \& transl. C. Emerson University of Minnesota, Minneapolis, MN.

Barr, J., 1993, Biblical faith and natural theology, Clarendon, Oxford.

Beal, T.K., 1992, 'Ideology and intertextuality: Surplus of meaning and controlling the means of production', in D.N. Fewell (ed.), Reading between texts: Intertextuality and the Hebrew Bible, Literary currents in biblical interpretation, pp. 27-39, Westminster John Knox Press, Louisville, KY.

Beal, T.K., 2000, 'Intertextuality', in A.K.M. Adam (ed.), Handbook of postmodern biblical interpretation, pp. 128-130, Chalice Press, St. Louis, MO.

Brenton, L.C.L., [1986] 2007, The Septuagint with Apocrypha: Greek and English, Hendrickson Publishers, Peabody, MA.

Caponigro, M.S., 1992, 'Judith, holding the tale of Herodotus', in J.C. VanderKam (ed.), No one spoke ill of her: Essays on Judith, Society of Biblical Literature: Early Judaism and its literature, vol. 2, pp. 47-60, ScholarsPress, Atlanta, GA.

Craven, T., 1983, Artistry and faith in the book of Judith, Dissertation series 70, Society of Biblical Literature, Scholars Press, Chico, CA.

Craven, T., 1993, 'Judith', in W.A. Meeks (ed.), The HarperCollins study Bible, pp. 1459-1480, HarperCollins, New York, NY. 
Culler, J., [1981] 2001, 'Presupposition and intertextuality', in J. Culler (ed.), The pursuit of signs: Semiotics, literature, deconstruction, augmented edn., pp. 100-118, Cornell University Press, Ithaca, NY.

DeSilva, D.A., 2002, Introducing the apocrypha: Message, context, and significance, Baker Academic, Grand Rapids, MI.

Dombkowski Hopkins, D., [1992] 1998, 'Judith', in C.A. Newsom \& S.H. Ringe (eds.), Women's Bible commentary, expanded edn., pp. 279-285, Westminster John Knox Press, Louisville, KY.

Efthimiadis-Keith, H., 2002, 'Text and interpretation: Gender and violence in the Book of Judith, scholarly commentary and the visual arts from the Renaissance onwards', Old Testament Essays 15(1), 64-84.

Esler, P.F., 2001, “"By the hand of a woman": Culture, story and theology in the book of Judith', in J. Pilch (ed.), Social scientific models for interpreting the Bible: Essays by the context group in honor of Bruce J Malina, Biblical interpretation series 53 pp. 64-101, Brill, Leiden.

Fewell, D.N., 1992, 'Introduction: Writing, reading, and relating', in D.N. Fewell (ed.), Reading between texts: Intertextuality and the Hebrew Bible, Literary currents in biblical interpretation, pp. 11-20, Westminster John Knox Press, Louisville, KY.

Flesher, L.S., 2007, 'The use of female imagery and lamentation in the book of Judith: Penitential prayer of petition for obligatory action?', in M.J. Boda, D.K. Falk \& R.A Werline (eds.), Seeking the favor of God: The development of penitential prayer in second temple Judaism, vol. 2, Early Judaism and its literature 22, pp. 83-104, Society of Biblical Literature, Atlanta, GA.

Geertz, C., 1964, 'Ideology as a cultural system', in D.E. Apter (ed.), Ideology and discontent, pp. 47-76, Free Press of Glenco, New York, NY.

Glancy, J.A., 1996, 'The mistress-slave dialectic: Paradox of slavery in three LXX narratives', Journal for the Study of the Old Testament 72, 71-87. http://dx.doi. org/10.1177/030908929602107205

Haberer, A., 2007, 'Intertextuality in theory and practice', Literature (Literatūra) 49(5), 54-67, viewed 25 August 2010, from http://www.ceeol.com

Harrington, D.J., 1999, Invitation to the Apocrypha, William B. Eerdmans Publishing Company, Grand Rapids, MI.

Jordaan, P.J. \& Kanonge, D.M., 2006, 'Women (whores?), wars and wisdom' Ekklesiastikos Pharos 88(17), 68-78.

Kavanagh, J.H., 1990, 'Ideology', in F. Lentricchia \& T. McLaughlin (eds.), Critical term for literary study, pp. 306-320, University of Chicago Press, Chicago, IL.

Kelle, B.E. \& Ames, F.R. (eds.), 2008, Writing and reading war: Rhetoric, gender, and ethics in biblical and modern contexts, Symposium series 42, Society of Biblical Literature, Atlanta, GA.

Kristeva, J., 1980, Desire in language: A semiotic approach to language and art, ed. L.S. Roudiez, transl. T. Gora, A. Jardine \& L.S. Roudiez, Columbia University Press, New York, NY.

Malina, B.J., 2001, The New Testament world: Insights from cultural anthropology, rev. \& expanded edn., Westminster John Knox Press, Louisville, KY

Miscall, P.D., 1992, 'Isaiah: New heavens, new earth, new book', in D. Nolan Fewell (ed.), Reading between texts: Intertextuality and the Hebrew Bible, Literary currents in biblical interpretation, pp. 41-56, Westminster John Knox Press, Louisville, KY.

Mitošinková, Z., n.d., Tracing intertextuality, pp. 64-68, viewed 25 August 2010, from http://www.pulib.sk/elpub2/FF/Ferencik2/pdf doc/8.pdf
Moi, T., 1986, 'Introduction', in J. Kristeva (ed.), The Kristeva reader, pp. 1-22, Columbia University Press, New York, NY.

Moore, C., 1985, Judith: A new translation with introduction and commentary, Doubleday, Garden City, NY. (Anchor Bible, 40)

Newsom, C.A., 2000, 'Bakhtin', in A.K.M. Adam (ed.), Handbook of postmodern biblical interpretation, pp. 20-27, Chalice Press, St. Louis, MO.

Nickelsburg, G.W.E., 2005, Jewish literature between the Bible and the Mishnah, Fortress Press, Minneapolis, MN.

Orr, M., [2003] 2008, Intertextuality: Debates and contexts, Polity Press, Cambridge.

Phillips, P., n.d., Biblical studies and intertextuality: Should the work of Genette and Eco broaden our horizons?, viewed 21 August 2010, from http://www. postmodernbible.blogs.com/Intertextuality.doc

Prinsloo, W.S., 1984, Van kateder tot kansel, NG Kerkboekhandel, Pretoria.

Rashkow, I.N., 1992, 'Intertextuality, transference, and the reader in/of Genesis 12 and 20 ', in D. Nolan Fewell (ed.), Reading between texts: Intertextuality and the Hebrew Bible, Literary currents in biblical interpretation, pp. 57-73, Westminster John Knox Press, Louisville, KY.

Roitman, A.D., 1992, 'Achior in the book of Judith: His role and significance', in J.C. Vanderkam (ed.), No one spoke ill of her: Essays on Judith, Society of Biblical Literature: Early Judaism and its literature, vol. 2, pp. 31-45, Scholars Press, Atlanta, GA.

Rowlett, L.L., 1996, Joshua and the rhetoric of violence: A new historicist analysis, Journal for the Study of the Old Testament, suppl. 226, Sheffield Academic, Sheffield.

Ruether, R.R., 1983, Sexism and God-talk: Toward a feminist theology, Beacon Press, Boston, MA.

Sternberg, M., 1985, The poetics of biblical narrative: Ideological literature and the drama of reading, Indiana studies in biblical literature, Indiana University Press, Bloomington, IN.

Steyn, G.J., 2008, 'Beautiful but tough: A comparison of LXX Esther, Judith and Susanna', Journal for Semitics 17(1), 156-181.

Stratton, B.J., 2000, 'Ideology', in A.K.M. Adam (ed.), Handbook of postmodern biblical interpretation, pp. 120-127, Chalice Press, St. Louis, MO.

Van Aarde, A.G., 2009, 'Intertekstualiteit - ensiklopedie en argeologie: Matteus se voorstelling van Jesus as redder', HTS Teologiese Studies/Theological Studies 65(1), Art. \#156, 10 pages. http://dx.doi.org/10.4102/hts.v65i1.156

Van Henten, J.W., 1994, 'Judith as a female Moses: Judith 7-13 in the light of Exodus 17; Numbers 20 and Deuteronomy 33:8-11', in F. Van Dijk-Hemmes \& A. Brenner (eds.), Reflections on theology and gender, pp. 33-47, Kok Pharos Publishin House, Kampen.

Van Henten, J.W., 1995, 'Judith as alternative leader: A rereading of Judith 7-13', in A Brenner (ed.), A feminist companion to Esther, Judith and Susanna, pp. 225-252, Sheffield Academic Press, Sheffield.

Van Wolde, E., 1997, 'Intertextuality: Ruth in dialogue with Tamar', in A. Brenner \& C. Fontaine (eds.), A feminist companion to reading the Bible, pp. 426-451, Sheffield Academic Press, Sheffield.

White, S.A., 1992, 'In the steps of Jael and Deborah: Judith as heroine', in J.C. VanderKam (ed.), No one spoke ill of her: Essays on Judith, Society of Biblical Literature: Early Judaism and its literature, vol. 2, pp. 5-16, Scholars Press, Atlanta, GA.

Worton, M. \& Still, J. (eds), [1990] 1991, Intertextuality: Theories and practices, Manchester University Press, Manchester. 